https://doi.org/10.15407/scine16.06.104

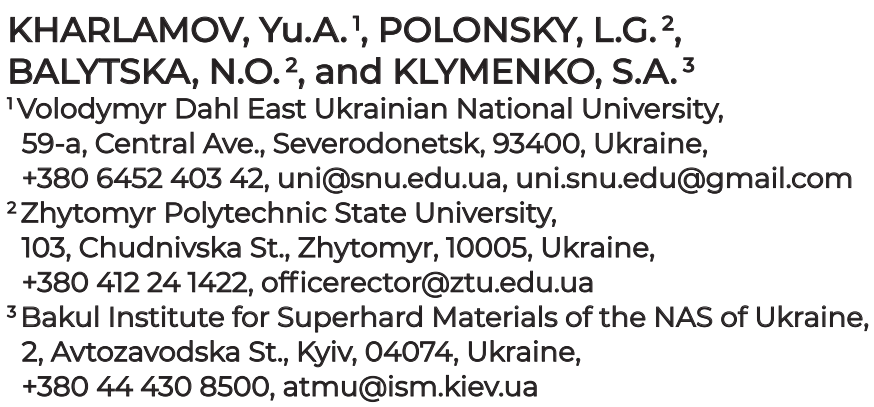

\title{
INNOVATIVE POTENTIAL OF GAS DETONATION
}

Introduction. Explosive technologies are widely used in the extraction industries, in mechanical engineering for welding, hardening, etc. However, the use of solid explosives is limited, above all, by safety requirements. Therefore, the use of a safer and more convenient source of energy, gas detonation, is attracting much attention. Pressures, temperatures, and velocities in detonation waves or shock waves in gases close to them in terms of intensity, as well as the pulse nature of the influence of these factors determine a high potential of their technical and technological use.

Problem Statement. In many technical systems, deflagration modes of burning prevail. However, a more thermodynamically advantageous method of combustion and conversion of chemical energy of fuel into useful work is the detonation mode of combustion. This ensures the feasibility of development, research and wider implementation of various technologies and devices using controlled gas detonation.

Purpose. Systematization and analysis of the main trends in the development and design of detonation gas technologies and devices in Ukraine and throughout the world.

Materials and Methods. Systematization and analysis of scholarly research publications and patents on the practical application of gas detonation in various sectors of the economy.

Results. The tendencies of practical use of gas detonation in different branches of industry have been revealed and analyzed. Priority developments in the technological application of the method in mechanical engineering have been performed in Ukraine. However, in many technical areas Ukraine has fallen behind the world leaders in terms of the creation of detonation gas technologies and devices.

Conclusions. For the practical use of the potential of gas detonation, it is necessary to develop fundamentally new devices that ensure reliable, safe, and controlable generation and propagation of detonation waves in gases and sprayed fuels. Gas detonation is promising for the creation of more advanced technologies and equipment.

Keywords: gas detonation, combustion, detonation-gas technologies, material processing, and branches of engineering.

Citation: Kharlamov, Yu.A., Polonsky, L.G., Balytska, N.O., and Klymenko, S.A. Innovative Potential of Gas Detonation. Sci. innoz. 2020. TV. 16, no. 6. P. 104-110. https://doi.org/10.15407/scine16.06.104 
The basic structures of technical systems (TS) for the implementation of the necessary functions are based on various physical and technical effects among which the processes of fuel combustion are rather often used. Today, TS mainly use the deflagration combustion conditions, in which flame spreads at subsonic speeds. However, the detonation combustion conditions, in which flame propagates at supersonic speeds, have been well known and studied by fundamental science for more than a hundred years. Of particular interest is gas detonation (GD) in combustible gases mixed with oxidants or sprayed liquid fuel. GD is self-sustaining combustion propagation conditions characterized by a complex of shock wave and subsequent area of exothermic chemical reactions initiated by shock compression [1]. This complex is called detonation wave that propagates at supersonic speeds.

The detonation wave front is the surface of hydrodynamic normal discontinuity. The gas blend is heated during while passing through the shock wave front. If the shock wave is strong enough, the temperature behind its front may exceed the self-ignition temperature, with exothermic chemical reactions running in the gas blend. In the course of these reactions, energy that feeds the shock wave is released. In deflagration combustion that propagates at subsonic speeds, the energy is transferred to the initial blend mainly by thermal conductivity. Certain conditions are necessary for GD - it shall be initiated by external influences (mechanical or thermal). Only in exceptional cases, slow burning can spontaneously lead to detonation.

The propagation speed of the explosive wave front relative to the initial gas blend (detonation rate) depends only on the composition and state of the detonating blend and can reach several kilometers per second.

Thermodynamically detonation is the most efficient way of direct fuel combustion and in the case of its use, engines and other devices have the maximum possible thermodynamic efficiency [1]. Gas parameters in the detonation combustion are much higher than in the conventional combustion. During detonation in the combustion chamber, the pressure of the combustion products that expand, cool, and are released into the surrounding space freeing the space for a new portion of gases increases sharply. In pulsating GD devices, the cycle is repeated with a certain frequency. The principles and devices for continuous GD are being developed.

High temperature, pressure, and speed in GD make the application of this phenomenon in technology rather promising.

Explosive technologies are increasingly used in various industries: mining, mechanical engineering, and so on. However, the use of solid explosives is limited primarily because of safety requirements. Gas detonation is a safer and more convenient source of energy. The level of pressure, temperature, and speed in detonation shock waves in gases or waves close to them in terms of intensity, as well as the pulsed nature of the influence of these factors determine a significant potential for their technical and technological use. Controlled gas detonation has recently been widely used in power engineering, as well as for the creation of new efficient engines and technologies for obtaining and processing materials with unique properties and so on. Detonation gas technologies and devices have prospects for further development, and the relevant developments can be used in innovative projects.

The purpose of this research is to identify, to systematize, and to analyze the main trends in the design and development of detonation gas technologies and devices in Ukraine and worldwide. To this end, scholarly research publications and patents of domestic and foreign researchers on the practical application of gas detonation in various fields of science and technology have been systematized and reviewed.

As a result of in-depth analysis of scholarly research sources, the trends in the practical use of gas detonation as an energy source by industry have been identified and analyzed. Thus, priority developments for the technological application of 
GD in mechanical engineering have been made in Ukraine. However, in many scientific and engineering areas there is a gap in $\mathrm{R} \& \mathrm{D}$ for the creation and wider use of detonation gas technologies and devices. This concerns power engineering industries, the creation of new engines, and others. The promising innovative directions of the use of GD in economic industries are described in more detail below.

\section{Power engineering and engines}

Heating devices. If the problem of cyclic detonation of conventional fuel air blends (natural or associated gas, coal particles, fuel oil, etc.) is successfully solved, significant fuel savings and a reduction in the release of harmful substances due to a very short detonation cycle are expected [2]. The conventional burners are based on the principle of normal slow combustion of natural gas (deflagration), with the maximum flame temperature not exceeding $1900{ }^{\circ} \mathrm{C}$ and the speed being 200-220 m/s. The use of pulsed detonation combustion of the gas-air blend provides a much higher technological level of the conversion of fuel chemical energy into thermal energy and mechanical work. A sevenfold growth in the flow rate of combustion products increases the heat transfer from detonation products to a coolant due to a sharp increase in the convective component. The use of pulsed detonation burners (PDB) will significantly increase the technological, environment, and economic efficiency of heating processes in industry.

Pulsed cleaning of convective heating surfaces from ash deposits by emissions of gas detonation products increases the efficiency of heat exchange and operation of steam and water boilers and process units that burn different types of liquid and solid fuels and ensures fuel economy [3]. Cleaning is based on the impact of the shock wave and combustion products emanating from the combustion chamber on the deposits on the heating surfaces. Ash deposits from flue gases on the heating surfaces reduce the efficiency of units (by $2-3 \%$ ). Gas-pulse cleaning enables maintaining the cleanliness of the heating surfaces and the ef- ficiency of the units close to the design parameters. This technology has been already widely used in industrial boilers, recovery boilers in metallurgical, chemical, and petrochemical industries, heating furnaces of refineries, etc.

Pulse detonation engines (PDE). Back in 1940, Ya. B. Zeldovich proved that direct-flow air-jet engines that used detonation combustion of fuel should have the maximum possible thermodynamic efficiency. Researches on the creation of pulsed detonation engines (PDE) are particularly active in the United States and the Russian Federation, where they have reached the R\&DD stage. Large-scale works are done at Pratt $\mathcal{E}$ Whitney (USA) and General Electric (USA). Aircraft power plants, the operation of which is based on the principle of gas detonation, will provide fuel savings of up to $30 \%$ at a Mach number of 2.5 and up to $20 \%$ at a Mach number of 3 , as well as an increase in the flight range of aircraft equipped with such engines or replacement of much of the fuel with payload $[4,5]$. The main areas of application of such engines are cost-effective ammunition deliveries, propulsion engines for pilotless target aircraft and unmanned aerial vehicles, and cruise missiles. In the future, they can be used to boost the thrust of manned aircraft. The U.S. Navy has been developing a detonation gas turbine unit to be installed on surface ships instead of conventional gas turbine engines. Power plants for natural gas detonation (in particular, power plants for gas pumping units of main gas pipelines) are also being developed in order to reduce the consumption of natural gas by gas transmission companies [4].

\section{Oil and gas industry}

At present, technical solutions for the use of gas detonation for impacting the fractured reservoir of hydrocarbons (oil wells) to increase the final oil recovery of the reservoir and the flow rate of wells are being developed [6]. Detonation combustion is used to increase the reliability of ignition of gas burners of elevated and ground-type flare systems for combustion of waste gases and multiphase systems of industrial effluents in gas 
and oil fields, in petroleum, chemical, and petrochemical industries [7].

Detonation gas spraying (DGS) of reinforcing coatings is used to increase the abrasive resistance of drilling tools (cones, three-cone and diamond drill bits), to restore and to strengthen equipment parts [8]. The penetrating capacity of multilayer lining for perforating oil and gas production wells made with the help of DGS increases by $25-35 \%$.

\section{Mining industry}

Thermodynamic drills for the destruction of strong rocks, with the use of detonation combustion, provide a 2-2.5-time increase in the yield of block stone (granite) of high quality [9]. Russia and the United States have carried out studies to create bulldozers with a gas-pulse unit [10].

Gas detonation mills are being developed for grinding of materials, in particular for fine and ultrafine grinding of, for example, pigments, which reduces the energy consumption of grinding processes [11].

\section{Metallurgical industry}

Pulse-detonation gas burners for industrial furnaces and thermal power plants provide a reduction in the specific consumption of natural gas by at least $8-10 \%$; an increase in the rate and, accordingly, a reduction in the time of the heating process; and a reduction in oxidation losses. In addition, these technologies optimize the use of production space, increase the service life of burners, reduce the cost of environment measures, etc. [10].

Some enterprises use pulse cleaning of heating surfaces of recovery boilers [12]. For dividing high-grade hot steel billets into parts on machines for continuous casting of billets, pulse cutting machines that use drives with the pulse combustion of combustible blend have been introduced in rolling production [13].

\section{Chemical and petrochemical industry}

Gas-phase detonation synthesis is used to obtain polycrystalline and nanosized titanium dioxide, nanoglobular carbon, including precursors for the production of fullerenes, carbon nanotubes, graphene, carbines, and others. [14, 15].
Treatment of dispersed particles by gas detonation is used to obtain metal oxides from their salts, to rearrange the crystalline structure of metals or to evaporate liquid from solutions for obtaining solids or solid solutions, amorphous and quenched powders, to spheroidize and to reduce oxide powders, to obtain acetylene black and highly-dispersed powder of lead zirconate titanate that is widely used for the production of radio components based on electronic ceramics, etc. [16].

Mechanical engineering/machine building is a leading industry in the development and use of detonation gas technologies and devices, many of which are designed in Ukraine. While processing metals by pressure, GD-based devices are used for pulse cutting of cold rolled products by short knives with a large wedge angle to obtain blanks from plastic steels, as well as from relatively brittle steels with a high content of carbon, manganese, etc. GD is also used to obtain blanks for further rolling, flash stamping of long products, as well as for face stamping [17], to manufacture high-speed power drives for free forging or hot stamping of parts in one or more transitions, to produce blanks and parts from difficult-to-form materials [13]. This technology is effective for stamping sheet metal and shaping sheet materials [17], in machines for pulsed briquetting of bulk materials, obtaining briquettes with a sufficiently high strength and density for remelting and shaping products, for example, inserts and plugs from cutting chips of ferrous metals to protect the closed bottom mold when pouring steel, consumable electrodes made of titanium sponge, as well as briquettes made of titanium alloy shavings and to compact the porous mass in gas cylinders [17].

The most well-known are the developments for detonation-gas spraying to ensure the production of coatings with increased strength and density, which have been made in Ukraine [17-20]. GD is also used in equipment for surface heat treatment (pulse plasma detonation generators) while reinforcing parts and tools; in thermochemical and thermopulse installations for removal of burrs, blunting of edges of arbitrary radius, 
cleaning from technological pollution of external and internal surfaces of details [21], jet-abrasive processing, etc.

\section{Construction and production of construction materials}

Technologies based on GD are used for destroying buildings (demolition of old buildings, structures, clearing of debris), eliminating ice congestion on rivers, and uprooting stumps. This technology is useful for improving the efficiency of destruction of large fragments of objects and for raising the safety of works by reducing the range of fragmentation [22], for destroying and developing, moving, laying, and compacting soils [10]. Soil compaction of the borehole space increases the bearing capacity of bored piles more than twice [22]. GD-compacted concretes have improved characteristics, their strength increases by $20-40 \%$.

\section{Agriculture and forestry}

Soil treatment by the GD method enables working on sown fields, as it does not damage young plants, and seed germination of cotton and corn increases by $15 \%$, the time of full germination decreases by $2-3$ days, the maturation of cotton shortens by $10-14$ days due to the acceleration of plant development in all phases. In addition, it improves the accumulation of nutrients in different parts of the plant (roots, leaves, stems, fibers) and therefore increases the yield of cotton by an average of $10 \%$ and raises the overall level of soil biological activity [23, 24]. GD is also used for pest and weed control, pre-sowing seed treatment, destruction of silkworm pupae, and cotton harvesting [24]. It is also effective to use GD for scaring away birds and wildlife animals to protect vineyards, orchards, rice and cereals, as well as at airports (to prevent birds from getting into aircraft engines) and fish farms (to scare birds away from water), etc.

\section{Geology and exploration}

Sources of seismic oscillations based on GD are used for searching and prospecting mineral deposits, as well as for engineering geological and hydro-acoustic surveys.

\section{Utilities}

Since the GD-based technologies are quite simple, affordable, and low-cost, they are used for restoring the productivity of water wells; for grinding and melting of snow and ice mass; for incinerating waste, and crushing tires for further processing.

\section{Emergency damage control/incident miti-} gation

GD-based technologies for throwing fire extinguishing substances, remote extinction of large fires, localization of forest fires (fire breaks) have been developed. To eliminate fires in buildings, knapsack periodic-pulse gas-water extinguishers have been designed. The use of GD-based systems for forced triggering of avalanches is also effective.

\section{Healthcare}

GD-based systems have been developed for needle-free injections, pain abatement, and tissue damage reduction.

\section{Soldiery}

GD is used in volumetric explosion munitions, demining (as compared with the manual method, the economic costs are reduced 5 times and the productivity increases more than 100 times), in gas detonation flamethrowers, when disposing of ammunition (crushing of solid explosive charges).

\section{Other applications of gas detonation}

The practical application of the gas detonation phenomenon is constantly expanding, increasing the number of relevant inventions and engineering solutions in various fields of management. An example is the initiation of combustion and explosion of solid and liquid explosives, in particular reliable initiation of simultaneous detonation of numerous dispersed charges; acceleration of compact bodies in ballistic and other experiments. The use of pulsed shock and convective thermal effects of a GD jet for gasification of heavy oil and coal fractions, household and industrial waste, crushing of rocks, ice, etc. is effective as well.

There are many fundamental and practical problems that prevent the use of gas detonation in de- 
vices. One of the key problems is the initiation of detonation in relatively short pipes (up to $1 \mathrm{~m}$ long) at a low ignition energy of the blend (up to several joules). Ensuring a rapid transition of combustion to detonation in hydrocarbon-air blends with minimal ignition energy is the most important fundamental problem, the solution of which opens the way for the practical use of gas detonation. The publications on this issue have been overviewed in [25].

Thus, for the practical use of gas detonation, it is necessary to develop fundamentally new special devices that ensure reliable, safe, and controlled triggering and propagation of detonation waves in gases and sprayed fuels. In Ukraine, effective technologies and equipment, which use gas detonation to spray coatings, to remove burrs, and to clean the surfaces of parts have been developed and implemented. Power engineering, the creation of new engines and heating devices are of particular interest for the application of GD.

Gas detonation as a physical and technical effect causes significant intersectoral interest in finding optimal technical solutions and is promising for the use in the conceptual design of new technologies and equipment.

It is also advisable to generalize the theory and practice of gas detonation with a description at the level suitable for physical and technical effects [26], as well as to create appropriate training and reference manuals on detonation gas technologies and equipment.

\section{REFERENCES}

1. Roya, G. D., Frolov, S. M., Borisov, A. A., Netzer, D. W. (2004). Pulse detonation propulsion: challenges, current status, and future perspective. Progress in Energy and Combustion Science, 30, 545-672.

2. Frolov, S. M., Aksenov, V. S., Avdeev, K. A., Borisov, A. A., Gusev, P. A., Ivanov, V. S., Koval', A. S., Medvedev, S. N., Smetanyuk, V. A., Frolov, F. S., Shamshin, I. O. (2013). Thermal tests of a pulse-detonation high-speed burner. Russian Journal of Physical Chemistry, 7(6), 748-752.

3. Pogrebnyak, A. P., Kokorev, V. L., Kokorev, A. L., Moiseyenko, I. O., Gultyayev, A. V., Yefimova, N. N. (2014). On the implementation of a system for impulse cleaning of the system. Experience in cooperation with boiler manufacturing enterprises. Heat supply newes, 1, 22-24 [in Russian].

4. Frolov, S. M. (2008) Pulsed detonation combustion: a new generation of power plants. Integral, 3(41), 44-45 [in Russian].

5. Frolov, S. M. (1996). Pulsed detonation engines. Moscow: Torus press [in Russian].

6. Kocharyan, G. G., Kostyuchenko, V. N., Budkov, A. M., Svintsov, I.S. (2003) A new seismic source and some prospects for its application. Geophysics, 6, 17-24 [in Russian].

7. Patent of Russian Federation N 2294485. Bolotov A. A., Krylov G. V. Method of gas-dynamic ignition of gas burners of flare devices [in Russian].

8. Kalashnikov, V. V., Demoretskiy, D. A., Nenashev, D. A., Trokhin, O. V. (2012) Development of advanced detonation technologies for the oil and gas industry. Electronic scientific journal "Oil and Gas Business", 4, 335-347 [in Russian].

9. Povetkin, V. V., Kerimzhanova, M. F., Bukayeva, A. Z. (2017) Development of a thermodynamic drill for breaking hard rocks. Progressive technologies and systems of mechanical engineering, 4(59), 56-63 [in Russian].

10. Explosive destruction of rocks (1979). Moscow: Nauka [in Russian].

11. Voytenko, A. Ye., Melikhov, V. P. (2006). Gas detonation mills. Science and innovation, 2(3), 111-113 [in Russian].

12. Shchelokov, Ya. M., Avvakumov, A. M., Sazykin, Yu. K. Cleaning of heating surfaces of waste heat boilers. Moscow: Energoatomizdat [in Russian].

13. Krivtsov, V. S., Maznichenko, S. A., Zastela, A. N., Obryvaeva, T. E. (2007). Impulse cutting of hot metal. Aerospace engineering and technology, 11(47), 26-34 [in Russian].

14. Li, S.-Tsz., Ouyan S., Yan, Kh.-Kh., Tsyuy, Ya.-D., Mo, F. (2008). Synthesis of $\mathrm{TiO}_{2}$ nanoparticles from titanium tetrachloride in the process of gas detonation. Combustion and explosion physics, 44(5), 112-116 [in Russian].

15. Yan, Kh.-Kh., Khuan, S.-Ch., Si, Sh.-S. (2014). The use of ethanol to produce nanosized titanium dioxide during gas detonation. Combustion and explosion physics, 50(2), 77-80 [in Russian].

16. Sychevskiy, V. A. (2008). Gas detonation treatment of particles. Thermal physics of high temperatures, 46(5), $751-759$ [in Russian].

17. Kharlamov, Yu. A., Budag'yants, N. A. (1998). Detonation and gas processes in industry. Lugansk: VUGU [in Russian]. 
18. Shorshorov, M. Yu., Kharlamov, Yu. A. (1978). Physical and chemical bases of detonation-gas spraying of coatings. Moskva: Nauka [in Russian].

19. Zverev, A. I., Astakhov, Ye. A., Sharivker, S. Yu. (1979). Detonation coating. Leningrad: Sudostroyeniye [in Russian].

20. Borisov, Yu. S., Kharlamov, Yu. A., Sidorenko, S. L., Ardatovskaya, Ye. N. (1987). Gas-thermal coatings from powder materials: a Handbook. Kyiv: Naukova dumka [in Russian].

21. Trifonov, O. V. (2013). The current state of technology and equipment for cleaning from burrs with detonating gas mixtures and directions for their improvement. Design and production of aircraft structures, 1, 115-121 [in Russian].

22. Kakenov, K. S. (2012). Modern methods of soil compaction explosive effects. Analysis of the consequences of emergency explosions. Karaganda: KEU [in Russian].

23. Panov, I. M., Vetokhin, V. I. (2008). Physical fundamentals of soil mechanics. Kyiv: Feniks [in Russian].

24. Tozhiyev, R. Zh. (1993). Mechanical-technological solutions of non-contact impact on the soil and plants with the development of gas-detonation units for highly efficient cultivation of cotton. PhD (Tech.) Moscow [in Russian].

25. Kharlamov, Yu. A. (2017). Controlled initiation of gas detonation. Visnik of the Volodymyr Dahl East Ukrainian national university, 7(237), 101-113 [in Russian].

26. Polovinkin, A. I. (1988). Fundamentals of Engineering Creativity. Moscow [in Russian].

Received 21.10.19

Revised 09.12.19

Accepted 17.02.20

\author{
Ю.О. Харламов ${ }^{1}$, Л.Г. Полонськийㄹ, Н.О. Балищька², С.А. Клименко ${ }^{3}$ \\ ${ }^{1}$ Східноукраїнський національний університет імені Володимира Даля, \\ просп. Центральний, 59-а, Сєвєродонецьк, 93400, Україна, \\ +380 6452403 42, uni@snu.edu.ua, uni.snu.edu@gmail.com \\ 2 Державний університет «Житомирська політехніка», \\ вул. Чуднівська, 103, Житомир, 10005, Україна, \\ +380 41224 1422, officerector@ztu.edu.ua \\ ${ }^{3}$ Інститут надтвердих матеріалів ім. В.М. Бакуля НАН України, \\ вул. Автозаводська, 2, Київ, 04074, Україна, \\ +380444308500, +38044468 8632, atmu@ism.kiev.ua
}

\title{
ІННОВАЦІЙНІ МОЖЛИВОСТІ ГАЗОВОЇ ДЕТОНАЦІЇ
}

Вступ. Вибухові технології знаходять широке застосування у видобувних галузях промисловості, в машинобудуванні для зварювання, зміцнення та ін. Однак використання твердих вибухових речовин обмежено, перш за все, вимогами безпеки. Тому все більшу увагу викликає використання більш безпечного й зручного джерела енергії - газової детонації. Рівень тисків, температур і швидкостей, що розвиваються за детонаційними або близькими до них за інтенсивністю ударними хвилями в газах, а також імпульсний характер впливу зазначених факторів, визначають високі потенційні можливості їх технічного та технологічного використання.

Проблематика. У багатьох технічних системах переважають дефлаграційні режими горіння. Однак термодинамічно вигіднішим способом спалювання і перетворення хімічної енергії палива в корисну роботу є детонаційний режим горіння. Це обумовлює доцільність розробки, дослідження і більш широкого впровадження різноманітних технологій і пристроїв з використанням керованої газової детонації.

Мета. Систематизація та аналіз основних тенденцій розвитку та розробки детонаційно-газових технологій і пристроїв в Україні та світі.

Матеріали та методи. Систематизація та аналіз наукових публікацій і патентів щодо практичного застосування газової детонації в різних сферах економіки.

Результати. Виявлено та проаналізовано тенденції практичного використання газової детонації в різних галузях промисловості. Пріоритетні розробки з технологічного застосування методу в машинобудуванні виконано в Україні. Проте за низкою технічних напрямків спостерігається відставання науково-дослідних робіт зі створення детонаційногазових технологій і пристроїв.

Висновки. Для практичного використання можливостей газової детонації необхідною є розробка принципово нових пристроїв, що забезпечують надійне, безпечне й кероване виникнення і поширення детонаційних хвиль в газах і розпорошених паливах. Газова детонація є перспективною для створення більш досконалих технологій та обладнання.

Ключові слова: газова детонація, горіння, детонаційно-газові технології, обробка матеріалів, галузі техніки. 